\title{
INFORMATION ECONOMY AS A FACTOR OF RURAL DEVELOPMENT
}
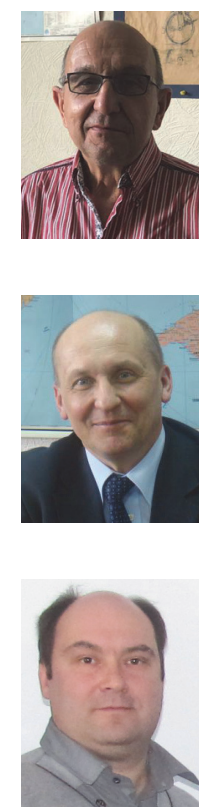

SKRYPNYK Andrii Vasyliovych - Doctor of Economics, Professor, Head of the Economic Cybernetics department, National University of Life and Environmental Sciences of Ukraine ORCID 0000-0002-2957-1355 E-mail:avskripnik@ukr.net

TALAVYRIA Mykola Petrovych - Doctor of Economics, Professor, Head of the Economic Theory Department, National University of Life and Environmental Sciences of Ukraine

E-mail: talanik@ukr.net ORCID 0000-0001-6915-4815

\author{
SAYAPIN Serhii Petrovych - Senior Lecturer, Information \\ System Department, National University of Life \\ and Environmental Sciences of Ukraine \\ E-mail: sayapin_sp@ukr.net \\ ORCID 0000-0003-1565-4034
}

\begin{abstract}
The paper substantiates the feasibility of introducing a binary system of agricultural advisory, which is represented by the structure of classical advisory services and leading agrarian universities and scientific institutions using the technological web platform of electronic advisory. An interactive information platform for rural information support has been proposed, with structure adaptation to effectively engage the existing advisory system. A similar system has already been established and is successfully operating in the United States.

In order to demonstrate the capabilities of the system, the dependence of productivity on the scale of production was analyzed. The estimation of productivity growth is made for the enterprises which do not fully use innovative technologies. Based on the results of the analysis, estimates of the country's gross grain and leguminous crops growth are estimated, which is 29\% of the 2018 gross harvest. The agrarian segment of information space of official information sources is analyzed. The directions of advancement development with the use of modern information technologies are offered. The advantages of implementing electronic advisory system for different categories of users are highlighted. The potential volume of binary system services for innovative development of small and medium-sized businesses is analyzed. As a client base are considered households, farms and agricultural enterprises with a land use volume not exceeding one thousand hectares. It is shown that large agricultural business uses
\end{abstract}


information directly from the world innovation centers of agricultural orientation. Much attention was paid to the problem of providing information to rural residents.

Keywords: information space; the effect of scale; electronic agricultural advisory services; digital divide; . households; farming; agricultural enterprises.

\section{Problem definition:}

During the Ukraine independence, there has always been a problem of lagging behind the economic and social development of rural areas, which has remained since the time of the planned economy. By the way, during the period, attempts were made to administratively consolidate settlements in order to present the possibility of obtaining a more complete package of available services to the local population $[12,16]$. During the years of independence, many economic and social development strategies were developed, which were aimed primarily at overcoming the significant lag of rural development $[4,14]$. However, from year to year, the situation has only worsened: the level of wages in rural areas has fallen behind the indicator in the whole country, the unemployment rate has exceeded the similar indicator in cities, and every year the number of villages in which there are no inhabitants is increasing [11,12].

The economic and social problems in the rural areas were generated by demographics, which in turn influenced the economic ones, creating a "degradation spiral" [2]. Perhaps the first steps in the right direction were financial decentralization (redistribution of financial resources between state and local budgets) and the creation of territorial communities by bringing together small villages, settlements and small cities [1]. However, a significant proportion of such communities remain subsi- dized (existing through state budget subsidies) due to the practical absence of operating budget-forming economic entities for taxes and fees that remain in local budgets [3]. Interestingly, the lack of a tax base capable of financing local budgets is against the backdrop of the steady growth of an export-oriented large-scale agricultural business. At present, only a portion (65\%) of the personal income tax remains stable in the budgets of territorial communities, but rural employment is steadily decreasing and this process will continue with the growing role of robotics in agricultural production of large enterprises. A large proportion of the tax revenues of large agricultural businesses remain at the place of incorporation, usually in large cities, but factually, the budgets of territorial communities can only be supported by small and medium-sized businesses [5].

It includes small and medium-sized farms and households that not only rent out units but also rent out to villagers. Only the development of this segment of agrarian business, whose interests usually remain beyond research, can support the budgets of rural territorial communities. And today, the experience of successful farming brings this into practice.

The resources that exist for the development of small and medium-sized businesses in rural areas are considered. It should be emphasized that it is not necessary for the business to relate from the production of agricultural products. These 
could be green tourism facilities, energy supply to the national electricity grid through the use of "green" tariffs, growing organic products, including for pharmaceuticals, recreational use of natural conditions. The standard resource approach in the economy is the availability of labor and capital, and for agricultural production the availability of land is a separate factor. However, there is one more important factor that needs to be taken into account is the impact of innovation, which allows agricultural products to be produced at prices that are growing at a rate lower than inflation. At present, the economy is becoming increasingly informational, ie based on the comprehensive use of information as an influential factor for economic development [22]. In the agricultural sector, the information economy is primarily concerned with the introduction of innovation, but the use of the information economy is much broader. In particular, it is information on the state of the finished product markets and the components of the manufacturing process; it is also an analysis of the production risks specific to the region.

According to Ukrainian agrarian business, there is a significant difference in getting information. Large agricultural enterprises, receive information directly from the world's leading agricultural innovation centers and small and medium-sized agrarian business receive information from the secondary local information market: (ie from various sources and origin from different sources and origin. communications, often the reliability of which is not confirmed, as well as the experience of large agricultural enterprises) [10].

Given the low level of employment in the countryside and the steady tendency to further decrease it, there is no shortage of this resource component, and the introduction of the land market in the future causes a significant flow of capital to the population of rural territories [9], which owns the shares, and produces commodity production. Therefore, in our opinion, the biggest problem is due to the lack of a quality information component of the process of emergence and development of small and medium-sized businesses.

The purpose of the presented paper is to analyze the potential of the information economy in closing the information gap between small and large agricultural businesses in order to develop all spheres of agrarian entrepreneurship on the basis of a modern information base.

\section{Analysis of recent research and publications.}

A feature of the digital economy is the increasing speed at which digital information is collected, analyzed and used. This information can be a reflection of any aspect of life: an individual, a social or business structure that resides on separate digital platforms. Global Internet traffic has grown from 100 gigabytes (GB) per day in 1992 to $45,000 \mathrm{~GB}$ per second in 2017, with plans to reach 150,700 GB per second in 2022 [22].

There is an intense debate in the scientific literature regarding the impact of digitization on the dynamics of information technology jobs. The consequences of digitization can vary significantly across countries, depending on factors such as the level of economic development, the structure of production and the labor market, the technological and social characteristics of the country. This should take into account government actions aimed at adapting those who are most likely to lose their jobs. $[20,23]$. 
The digital economy, based on digital technologies with business models based on digital goods and services, has extremely high prospects in developing countries. However, this potential is extremely difficult to achieve due to underdeveloped and extremely costly infrastructure. In addition, there is a lack of sufficient skilled labor and quality funding. There are inverse selection, inequality, corruption and unqualified management [19].

Digital education, which precedes any decision-making process, can be used for various economic, political and social purposes. The impact in the digital economy is largely determined by the appropriate use of digital intelligence. Digital education becomes "digital capital" if the result is: 1) access to a large amount of data; 2) control over their use; 3 ) skilled processing that enables the transformation of data into digital intelligence; and 4) enables use in manufacturing processes. The economic value of this digital capital is generated through various forms of data monetization [26].

Companies specializing in artificial intelligence technology can relatively easily move into new industries and deploy their services there. For example, these companies are moving into industries such as energy, healthcare and transportation, where revenues are much higher than in the advertising industry, as in the classic application area [25].

In Ukraine, information processing and analysis companies often become owners of inefficient agricultural enterprises, but they face considerable difficulties in replacing existing staff with more qualified and inconsistent criminal acts [10].

The digital economy and the digitization of particular industries should be distinguished directly. Today, some industries are not directly involved in the digitalization process, but may feel the impact of it. This is primarily due to the fact that the low-income share of the workforce will not be able to compete with employees who are more efficient in using digital technologies. An infrastructure or organization that is provided with an electronic platform can efficiently transmit and exchange online operational information that can be accumulated and made available for analysis in a necessary retrospective in a certain systematization. Quantitative and qualitative information makes it easier to market goods and services [22].

Many recent studies look at the differences between transaction and innovation platforms to analyze the opportunities and threats of platform development in each market [24].

In Ukraine, there are a large number of electronic platforms for disseminating useful information to farmers. However, in our view, the level of digitization of these platforms and the supply of the final product that can be used for decision-making in the agricultural sector or by residents of rural areas is not sufficient. The issues of accumulation and further dissemination of knowledge have not been fully resolved. The number of priority issues that need to be addressed in the first place has not been determined $[6,8]$. In our view, it would be useful to digitize the agrarian sector by using trends in Iowa counseling, where more than $90 \%$ of farmers use the advice of private advisors, $80 \%$ of whom, in their turn, consider the department of Iowa to be a source of agrarian innovation. That is, the primary source of information (university) focuses not on the end consumer - the farmer, but on a more qualified mediator (advisor) [18] An interesting practical aspect of this 
is that the originator of the request for innovative information is often not the farmer, and it is the advisor who reports this information. And its acceptance is facilitated not only by the knowledge of the consultant's current needs, but also by the degree of readiness and demand for innovation for the future.

It is well known that in the agrarian sphere a significant and influential factor of sustainable development is to take into account many risks related to both the nature of agricultural production and the inherent factor of incompleteness of institutional transformations in the Ukrainian agrarian sector. Recently, uncertainty has emerged in the advisory process, which is linked to markets for major components of the crop production process, as well as methods of reducing institutional risks [10,27].

\section{Summary of the main results of the study.}

The growth of internet use has slowed down in recent years, suggesting that many low- and middle-income countries have significant prospects for improvement. Limited use of the Internet is an obstacle to the growth of the market for value creation in the digital economy [22]. The slowdown in the growth of high-speed (broadband) Internet users is partly due to their inability to allow basic network connectivity or to purchase appropriate devices. This fully applies to the rural population of Ukraine, where 8.2 million residents do not have access to broadband Internet [17].

We analyze in more detail the information inequality (digital divide) between rural and urban population of Ukraine. At present, there is a digital divide between opportunities to get information from local and rural populations, and digital inequality is growing. Table 1 presents the distribution of Internet users by the speed of obtaining information for cities and towns of different categories: 1) millionaires, 2) cities with a population of more than 100 thousand, 3 ) cities with a population of more than 10 thousand, and settlements with a population less 10,000 people (rural settlements fall into the latter category).

The weighted average speed of $\mathrm{M}(\mathrm{x})$ in million cities is $14.7 \mathrm{Mbps}$, while the weighted average speed in settlements 4 of category $9.8 \mathrm{Mbps}$. It should be emphasized that in the cities of millionaires there is also the greatest dispersion of speed of the Internet. In our opinion, this is explained by the fact that in big cities there is an opportunity to connect to really fast Internet (from 100Mbps), but the connection to the Ukrtelecom network with significantly slower speed remained. The modal value for all categories of cities and towns belongs to the interval of 12-20 Mbps, but the percentage of clients with a speed greater than the modal in the millionaire cities is significantly higher than in other categories. In our opinion, this means that in small towns and in rural areas, the issue of high-speed Internet (more than $50 \mathrm{Mbps}$ ) is not only related to cost, but rather determined by technical capabilities, but more likely by their lack.

This is even more true in rural areas, where 21.7 thousand villages $(8.2 \mathrm{mil}-$ lion inhabitants) remain without broadband at this time [17].

It is worth noting that fast enough $3 \mathrm{G}$ and $4 \mathrm{G}$ access through rural mobile networks is preferable, if any. In addition, the policy of facilitating internet access through smartphones (at least, an additional fee for using the phone as an access to Wi-Fi for Internet-oriented service packages), while in line with global 
Table 1. Internet speed for different categories of cities and towns in Ukraine

\begin{tabular}{|l|c|c|c|c|c|}
\hline & $\begin{array}{c}\text { Average } \\
\text { range, Mbps }\end{array}$ & 1 (top 6) & $2(100 \mathrm{~K}+)$ & $3(10 \mathrm{~K}+)$ & $4(-10 \mathrm{~K})$ \\
\hline $0-6 \mathrm{Mbps}$ & 3 & 0,16 & 0,19 & 0,29 & 0,31 \\
\hline $6-8 \mathrm{Mbps}$ & 7 & 0,09 & 0,12 & 0,15 & 0,15 \\
\hline $8-12 \mathrm{Mbps}$ & 10 & 0,17 & 0,23 & 0,20 & 0,16 \\
\hline $12-20 \mathrm{Mbps}$ & 16 & 0,48 & 0,44 & 0,35 & 0,36 \\
\hline 20-50 Mbps & 35 & 0,09 & 0,03 & 0,01 & 0,01 \\
\hline $50-100 \mathrm{Mbps}$ & 75 & 0,02 & 0,00050 & 0,00070 & 0,00040 \\
\hline 100 or more Mbps & 125 & 0,00002 & 0,00001 & 0,00005 & 0,00002 \\
\hline $\mathrm{M}(\mathrm{x})$ & & 14,71 & 11,69 & 10,03 & 9,84 \\
\hline $\mathrm{D}(\mathrm{x})$ & & 123,82 & 41,91 & 39,84 & 39,82 \\
\hline
\end{tabular}

Source: URL: http://internetua.com/v-ukraine-sokrasxaetsya-cifrovoi-razrv; own calculations.

trends, does not help to attract the whole economically active rural population as subjects of the digital economy.

That is, given the lack of broadband Internet in $65 \%$ of the rural population, the weighted Internet speed is reduced to $3 \mathrm{Mbps}$. The issue of access to broadband Internet is particularly relevant during institutional changes (transition to the agricultural land market. It is extremely important that each unit owner be able to verify the land and ownership through the Land Cadaster, and have an idea offers on the land market for the purchase / sale and lease by territorial section of the country.

In our view, another important distinction that distinguishes access to broadband Internet by urban and urban dwellers (last category 4) in rural areas should be noted. If in the first and the second category of cities access to high-speed Internet is only a matter of cost of services according to the chosen high-speed package, then for the latter category of the issue can be solved only at the expense of considerable investments in creation of networks of dissemination of information.

It is possible to improve the situation in the countryside through the informa- tion economy. Information is a fundamental economic force in making every economic decision. Many economic models are based on the assumption that all economic agents have perfect information in the decision-making process. This assumption is absolutely unacceptable for the Ukrainian agrarian sector, which operates under conditions of considerable asymmetry of information, which is caused by colossal asymmetry in economic scale [9]. Let's consider what effect you can expect from such a step. However, in the first stage, we consider a nonlinear scheme of information dissemination [22] in the digital economy on the basis of the digital platform of electronic advisory (Fig. 1).

Nonlinearity of the presented scheme is the presence of the impact of the digital platform on the production process at all stages, as well as the availability of customer feedback on the final product. The monetization of information occurs at the final stage of the advisory phase, where certified advisors provide the information directly, taking into account the risks and resource base of the individual client. This advisory system is binary when major recommendations are developed 
at the national level using the electronic advisory platform and are based on state support, using the potential of agrarian universities and research institutes of NASU and NAAS, and ultimately the recommendations are proven. In our view, the list of standard but topical issues that will be included in the eLearning platform knowledge library are issues related to the transition to the land market, investing in green energy; adapting to climate change and increasing efficiency in the crop sector, taking into account the risks in the livestock sector.

Demand for technologies that can be assisted by a binary advisory system can be justified on the basis of 2018 crop and legume crop observations for agrarian businesses of varying land uses [15]. With the help of econometric analysis, we an- alyze the data of the observations on the yield of cereals and legumes, depending on the scale of land use (Table 2).

The information presented in the table with the minimum error is described by the increasing logarithmic dependence of the yield on the areas of the plots (the coefficient of determination is 0.99). Marginal yield is a declining function of the square. That is, unlike the widely known study by Deninger [21], at first glance, the effect of scale-up has a positive effect, but the marginal effect decreases with the increase of scale of production. A more detailed analysis of the use of components of agricultural production shows that the lack of productivity is explained by the non-use of technologies already known and widespread in the field of crop production [15].

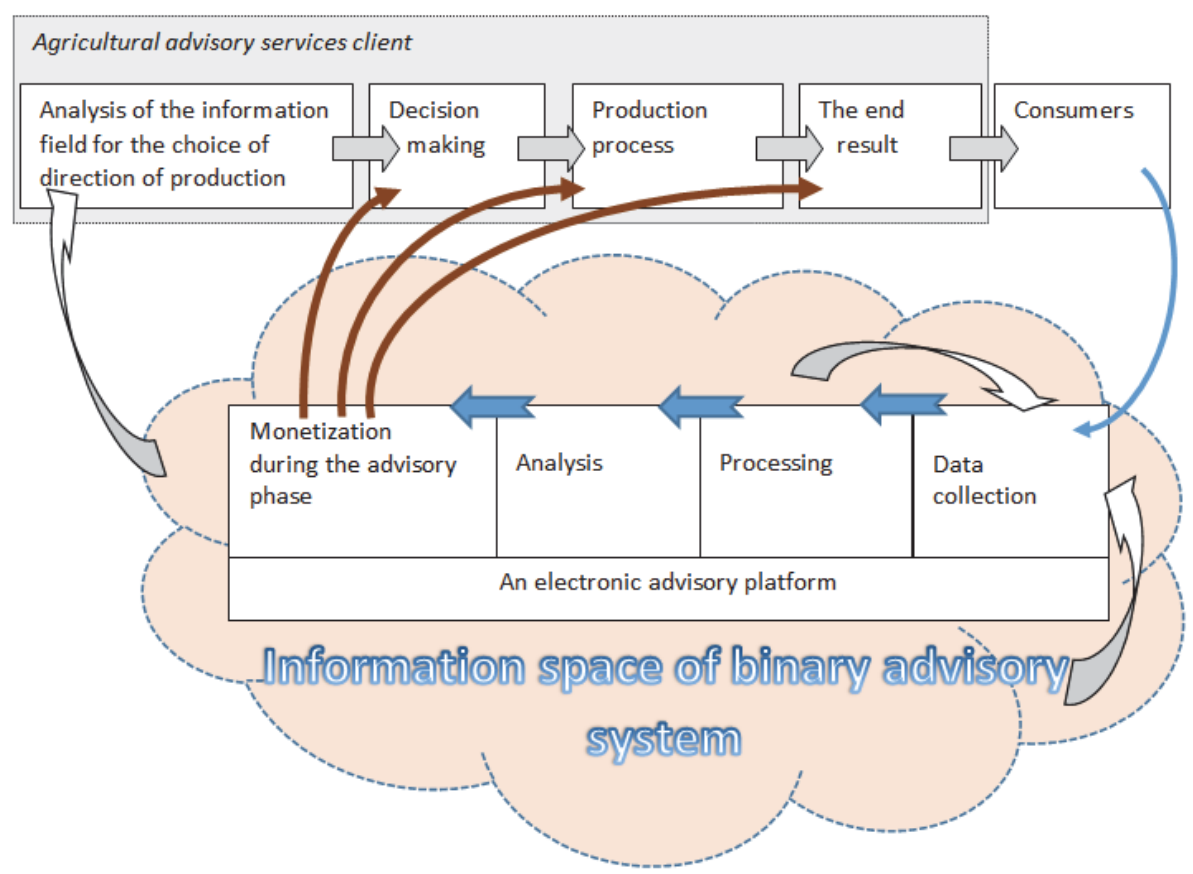

Figure 1. Scheme of non-linear information dissemination based on digital advisory platform

Source: own interpretation [19] 
Table 2. Data on crop and legume crop yields depending on the extent of land use

\begin{tabular}{|c|c|c|c|c|c|c|c|}
\hline Area (ha) -x & $\begin{array}{c}1-100 \\
(50)\end{array}$ & $\begin{array}{c}100-200 \\
(150)\end{array}$ & $\begin{array}{c}200-500 \\
(350)\end{array}$ & $\begin{array}{c}500-1000 \\
(750)\end{array}$ & $\begin{array}{c}1000-2000 \\
(1500)\end{array}$ & $\begin{array}{c}2000-3000 \\
(2500)\end{array}$ & $\begin{array}{c}3000- \\
(14200)^{*}\end{array}$ \\
\hline $\begin{array}{c}\text { Yield (kg/ } \\
\text { ha) -y }\end{array}$ & 33,2 & 41,2 & 45,7 & 47,9 & 52,1 & 54,9 & 65,6 \\
\hline $\begin{array}{c}\text { Model } \\
\text { value (c/ha) }\end{array}$ & 34,0 & 40,0 & 44,7 & 48,9 & 52,7 & 55,5 & 65,0 \\
\hline $\begin{array}{c}\text { Increase (t/ } \\
\text { ha) }\end{array}$ & 3,1 & 2,5 & 2,0 & 1,6 & 1,2 & 0,9 & \\
\hline $\begin{array}{c}\text { Square, } \\
\text { million } \\
\text { hectares }\end{array}$ & 0,9 & 0,5 & 1,4 & 1,9 & 3,5 & 2,6 & \\
\hline
\end{tabular}

${ }^{\star}$ The values of the areas of the last interval are obtained as the weighted average of the last two columns of the table. 2.

Source: State Statistics Committee's own interpretation.

The obtained dependence of the yield on the size of the area under cultivation, it is possible to estimate the magnitude of the yield increase due to the use of effective production technologies and on this basis to make an estimate of the increase in the gross harvest of grain and legumes in the country:

$$
\Delta V=\int_{0}^{X m} \Delta y(x) S^{\prime}(x) \cdot d x
$$

$\Delta V$ - increase in gross harvest in million tons, yield increase in $\mathrm{t} / \mathrm{ha}$,

$S^{\prime}(x)$ - function of density of distribution of areas by size of separate sites $\mathrm{X}$.

The distribution of farms and agricultural enterprises by number relative to the area under cultivation is presented in Table 3. The vast majority of farms $(76 \%)$ use plots not exceeding 100 ha. The largest number of agricultural enterprises is in the range of areas from 1 to 4 thousand hectares.

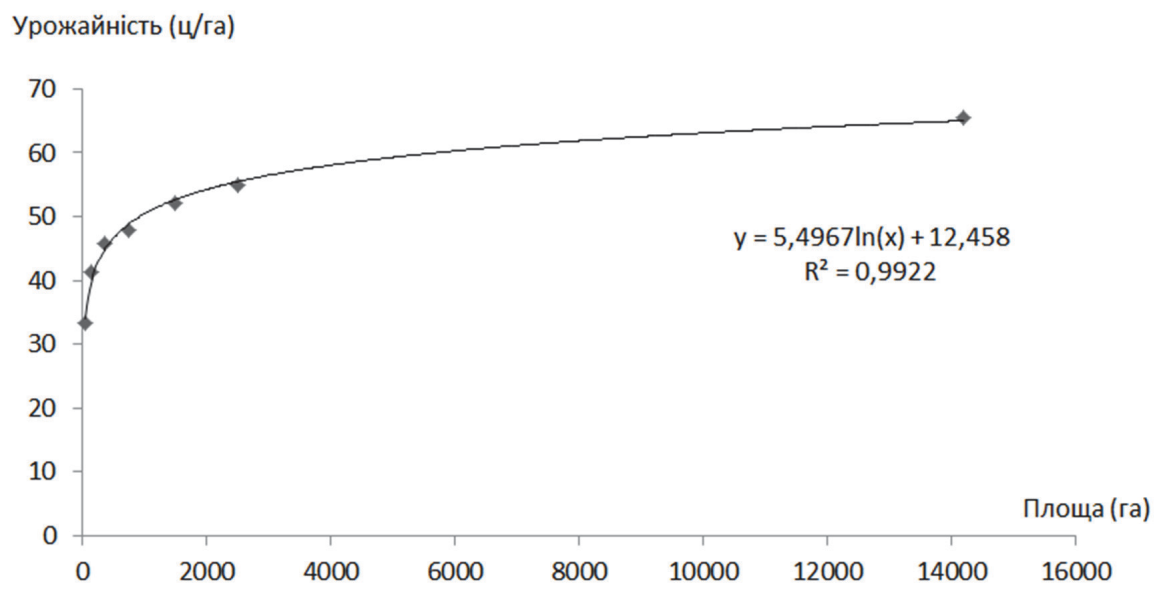

Figure 2. Observation data and logarithmic dependence of yield on area

Source: [13-16], own interpretation and calculations 
Table 3. Amount of land (million ha) of agricultural enterprises (AP) and farms (FY) as of 1.11. 2018

\begin{tabular}{|l|c|c|c|c|c|}
\hline Size (thousand ha) & $\mathrm{S}<0,1$ & $0,1<\mathrm{S}<1$ & $1<\mathrm{S}<4$ & $4<\mathrm{S}<10$ & $\mathrm{~S}>10$ \\
\hline Number of APs (\%) & $2101(21,1)$ & $3950(39,9)$ & $3111(31,4)$ & $570(5,8)$ & $180(1,8)$ \\
\hline AP area (million ha) & 0,09 & 1,73 & 6,22 & 3,29 & 4,00 \\
\hline AP area share (\%) & 0,5 & 8,7 & 31 & 16,4 & 19,9 \\
\hline The amount of FG (\%) & $23163(76,1)$ & $6327(20,9)$ & $866(2,8)$ & $65(0,2)$ & \\
\hline FY area (million ha) & 0,80 & 2,05 & 1,50 & 0,39 & \\
\hline FG area fraction (\%) & 3,9 & 10,2 & 7,5 & 1,9 & \\
\hline
\end{tabular}

Source: http://www.ukrstat.gov.ua/druk/publicat/kat_u/2019/zb/11/zb_yearbook_2018.pdf; https://land. gov.ua/wp-content/uploads/2018/10/monitoring.pdf: own interpretation

Based on the data of the table 2 and table 3 , we move from a continuous to a discrete estimate of the increase in the gross grain and legume collection across the country:

$$
\begin{gathered}
\Delta V=\sum_{i=1}^{6} \Delta y_{i} S_{i}=3,1 \cdot 0,9+2,5 \cdot 0,5+ \\
+2,0 \cdot 1,4+1,6 \cdot 1,9+1,2 \cdot 3,5+0,9 \cdot 2,6 \approx
\end{gathered}
$$

\section{$\approx 16,4$ million tons}

where $i$ the column index of the table 3 .

The possible yield increase is defined as the difference between the maximum model value of the yield and the model yield corresponding to the area of the plots $\mathrm{i}$ column $\hat{y}_{i}$, $\Delta y_{i}=\widehat{y}(14200)-\widehat{y}_{i} \quad \mathrm{~S}_{\mathrm{i}}-$ the area in million hectares, which corresponds to the range in table 3.

That is, with the current gross collection of cereals and legumes, the use of existing technologies in Ukraine can additionally bring 16 million tons of cereals and legumes. This can increase the gross collection by $29 \%$ from 56 to 72 million tonnes. If we calculate the lost money due to inefficient crop technologies in terms of this type of crop production, then we deny it at 2018 prices
(4315 UAH/t [7]), about $69 \mathrm{UAH}$ billion, this is an order of magnitude higher than the volume of budget subsidies of Ukraine for the whole agrarian sector.

By using innovative technologies aimed at sustainable rural development, not only the well-being of the population can be dramatically improved, but also many pressing social issues and environmental challenges, including the use of the renewable energy perspective, can be addressed. Information support regarding sources of investment and operational financing may also be the responsibility of advisory services. As such support may be offered in the context of the use of technology and sources of funding for innovation.

\section{Conclusions.}

Taking into account the foreign experience, a binary advisory system is proposed, consisting of an advisory platform, which is filled with information from government orders on the most urgent issues of agricultural and rural development, and specific consulting services are provided with the help of certified expert advisers.

Now days, there is a heterogeneity of Internet access for rural residents in relation to residents of large cities. 
Moreover, a large proportion of the rural population does not have access to broadband Internet at all, which does not contribute to the process of digitization of agricultural production and creates a significant differentiation of opportunities that gives rural residents the transition to the land market.

It is essential to emphasize that information becomes a commodity, and can only be monetized after its processing and analysis. In addition, information that meets the requirements of an individual household or farm can not be placed on the electronic platform. The issues should be resolved by experienced and certified advisers in the client's resources and make recommendations based on the stages of risk that the decision-maker or economic entity would choose.

The example of the production of grain and legumes shows that the use of technologies already known in Ukraine can significantly increase the gross harvest of these crops, and since this will be done at the expense of small businesses, a significant portion of the income will remain at the disposal of rural residents and territorial communities.

\section{References}

1. Biudzhetnyi kodeks Ukrainy No 2011-VIII vid 12.04.2017 [Elektronnyi resurs] // Vidomosti Verkhovnoi Rady Ukrainy (VVR) (2019). Retrieved from: http://zakon3.rada. gov.ua/laws/show/2456-17 [In Ukrainian].

2. Voropaiev V. Demohrafichni protsesy $v$ Ukraini yak predmet politychnoho menedzhmentu (2013) Retrieved from: http:// www.dy.nayka.com.ua/?op $=1 \& z=557 \quad$ [In Ukrainian].

3. Holovenko V.A.,Stan sotsialno-ekonomichnoho rozvytku Ukrainskoho sela ta yoho vplyv na stanovyshche simei (2006) Retrieved from: https://ukr-socium.org.ua/ wp-content/uploads/2006/07/99-117 no-3-4_vol-14_2006_UKR.pdf [In Ukrainian].

4. Kinska K. 2006-y stane rokom ukrainskoho sela // Uriadovyi kurier. - 2005. - 16 cherv. (2005) [In Ukrainian]

5. Kovalenko H., Diachenko M., Chukina O. Ohliad reform mistsevoho samovriaduvannia ta terytorialnoi orhanizatsii vlady v Ukraini (2018) Retrieved from: http:// www.dy.nayka.com.ua/pdf/5_2018/35.pdf [In Ukrainian].

6. Саяпін С. П. Saiapin, S.P. (2014). Chomu vyhidna systma elektronnoho doradnytstva (na prykladi veb-portalu Agroua.net) [Why the system of electronic advisory is profitable (on an example of Agroua.net web portal)]. Sbornik nauchnykh trudov Sworld, Vol. 3 (36), Issue 17, pp. 50-53 [In Ukrainian].

7. Realizatsiia produktsii silskoho hospodarstva pidpryiemstvamy ta hospodarstvamy naselennia u 2018 rotsi (2018) Retrieved from: http:// www.ukrstat.gov.ua/operativ/operativ2018/ sg/rpsg/rpsg1218.xls [In Ukrainian].

8. Systema elektronnoho doradnytstva eDorada.org (2019) Retrieved from: http:// edorada.org/.

9. Skrypnyk A., Tkachuk V., Andriushchenko V., Bukin E.( 2019.) Dosiahnennia rivnovahy na potentsiinomu rynku zemli Ukrainy $v$ umovakh makroekonomichnoi nestabilnosti $\mathrm{E}$. Ekonomika APK, 2. pp. 19-32. [In Ukrainian].

10. Skrypnyk, A. \& Bukin, E. (2017) Analiz efektyvnosti ta ryzykiv innovatsii $v$ ahrarnomu sektori ekonomiky Ukrainy: monohrafiia [Analysis of efficiency and risks of innovations in the agrarian sector of Ukrainian economy: monograph]. Kyiv: TsP Kompryn [In Ukrainian].

11. Sotsialno-ekonomichne stanovyshche domohospodarstv Ukrainy u 2018 rotsi (za danymy vybirkovoho obstezhennia umov zhyttia domohospodarstv). (2018) Retrieved from: http://ukrstat.gov.ua/ operativ/operativ2018/gdvdg/soc_ek_ stan_dom_2018.zip (дата звернення 28.10.2019 p.). [In Ukrainian]. 
12. Sotsialno-ekonomichnyi rozvytok Ukrainy. Arkhiv 2019. (2019) Retrieved from: http://ukrstat.gov.ua/operativ/operativ2018/so_ek_r_u/soekru_u/arh_soekru_19.htm [In Ukrainian].

13. Nemets L.,Mezentseva K.. (2019) Sotsialna heohrafiia : pidruchnyk za red.. Kyiv, Fenyks [In Ukrainian].

14. A.S. Holchinskyi, V,M, Heiets ta insh (2004) Stratehiia ekonomichnoho i sotsialnoho rozvytku Ukrainy na 2004-2015 roky: Shliakhom Yevropeiskoi intehratsii Kyiv: IOTs Derzhkostatu Ukrainy [In Ukrainian].

15. Statystychna informatsiia "Osnovni silskohospodarski kharakterystyky domohospodarstv u silskii mistsevosti v 2018 rotsi". (2018) Retrieved from: http://ukrstat. gov.ua/operativ/operativ2018/sg/opsgd/ oschd_2018_xl.xIsx [In Ukrainian].

16. Transformatsiia silskoho rozselennia v Ukraini (2017): kol. monohr. / za red. T.A. Zaiats ;. - Kyiv: Instytut demohrafii ta sotsialnykh doslidzhen im. M.V. Ptukhy NAN Ukrainy [In Ukrainian].

17. Цифровой разрыв: почему украинские села остаются без интернета (2018) Retrieved from: https://biz.liga.net/ all/telekom/article/tsifrovoy-razryv-pochemu-ukrainskie-sela-ostayutsya-bez-interneta [In Ukrainian].

18. Bahn H., McAleer P. (2019) U.S. Agricultural Extension Services: Adapting Farmer Education to Contemporary Market Requirements1 Retrieved from: http://www.ncap. res.in/Contract_\%20farming/Resources/12.1\%20Henry\%20Bahn.pdf [In English]

19. Bukht R., Heeks R. Digital Economy Policy in Developing Countries . 2018 https:// diodeweb.files.wordpress.com/2018/03/ digital-economy-policy-diode-pap [In English]

20. Das M. and Hilgenstock B (2018). The exposure to routinization: Labor market implications for developed and developing economies. Working Paper No. 18/135. IMF, Washington, DC [In English]

21. Deininger K., Nizalov D., Singh S. Are mega-farms the future of global agriculture? Exploring the farm size-productivity relationship for large commercial farms in Ukraine. Washington, 2013.

22. Digital Economy Report 2019 https:// unctad.org/en/pages/PublicationWebflyer.aspx?publicationid=2466 https://unctad.org/en/PublicationsLibrary/der2019_ en.pdf

23. Diode I. (2018). Digital Economy Policy in Developing Countries. Strategy Brief. Development Implications of Digital Economies. Manchester.

24. Evans $P$ and Gawer A (2016). The rise of the platform enterprise: A global survey. The Emerging Platform Economy Series, 1. The Centre for Global Enterprise, New York, NY.

25. Jovanovic B and Rousseau PL (2005). General purpose technologies. Working Paper No. 11093, NBER, Cambridge, MA.

26. Mayer-Schönberger V and Cukier K (2013). Big Data: A Revolution That Will Transform How We Live, Work, and Think. Houghton Mifflin Harcourt, Boston, MA

27. Morton, W., J.H. Lois, and J.G. Arbuckle, Jr. Shifts in farmer uncertainty over time about sustainable farming practices and modern farming's reliance on commercial fertilizers, insecticides and herbicides. J. Soil Water Conserv. 68:1-12. 2013. Doi:10.2489/.

\section{Скрипник А. В. , Талавиря М. П., Саяпін С. П. (2019). ІНФОРМАЦІЙНА ЕКОНОМІКА, ЯК ФАКТОР РОЗВИТКУ СІЛЬСЬКИХ ТЕРИТОРІЙ. БІОЕКО- НОНОМІКА ТА АГРАРНИЙ БІЗНЕС, 10(2): 111-123. http://doi.org//10.31548/ bioeconomy2019.02.111.}


Анотація. В роботі обгрунтується доцільність впровадження бінарної системи сільськогосподарського дорадництва, яка представлена структурою класичного дорадництва та провідними аграрними університетами й науковими установами з використанням технологічної веб-платформи електронного дорадництва. Запропоновано інтерактивна інформаційна платформа інформачійного забезпечення сільських територій з адаптачією структури для ефективного залучення існуючої системи дорадчих служб. Аналогічна система вже створено і успішно функиіонує в США.

3 метою демонстрації можливостей системи проаналізовано залежності урожайності від масштабу виробництва. Зроблено оцінку зростання урожайності для підприємств, що не використають в повною мірою інноваційні технології. Ґрунтуючись на результатах аналізу отримано оцінки зростання валового збору зернових та зернобобових в масштабі країни, який складає 29\% від валового збору 2018 року. Проведено аналіз аграрного сегменту інформаційно простору офріційних інформаційних джерел. Запропоновано напрямки розвитку дорадництва з використанням сучасних інформаційних технологій. Виокремлено переваги впровадження системи електронного дорадництва для різних категорій користувачів. Проаналізовано потенційний обсяг послуг бінарної системи для інноваційного розвитку малого та середнього бізнесу. В якості клієнтської бази розглядаються сільськи домогосподарства, фермерські господарства і аграрні підприємства з обсягом землекористування, що не перевищує 1 тис. га. Показано, що великий аграрний бізнес користується інформацією безпосередньо з світових інноваційних центрів аграрної спрямованості. Значну увагу приділено проблемі індормаційного забезпечення мешканців сільських територій.

Ключові слова: інформачійний простір; ефект масштабу; електронне сільськогосподарське дорадництво; иифровий розрив; домогосподарства; фермерство; аграрні підприємства.

\section{СКрипник А. В., Талавиря Н. П., СаяпИн С. П. (2019). ИНФОРМАЦИОННАЯ ЭКОНОМИКА, КАК ФАКТОР РАЗВИТИЯ СЕЛЬСКИХ ТЕРРИТОРИЙ. БІОЕ- КОНОНОМІКА ТА АГРАРНИЙ БІЗНЕС, 10(2): 111-123. http://doi.org//10.31548/ bioeconomy2019.02.111.}

Аннотация. В работе рассматривается целесообразность внедрения бинарной системы сельскохозяйственного консультирования, которая представлена структурой классического консультирования и ведущими аграрными университетами и научными учреждениями с использованием технологической веб-платформы электронного консультирования. Предложено интерактивная информационная платформа информационного обеспечения сельских территорий с адаптацией структуры для эффрективного привлечения существующей системы совещательных служб. Аналогичная система уже создана и успешно функционирует в США.

С целью демонстрации возможностей системы проанализированы зависимости урожайности от маситаба производства. Произведена оценка роста урожайности для предприятий, не используют в полной мере инновационные технологии. Основываясь на результатах анализа получены оценки роста валового сбора зерновых и зернобобовых в маситабе страны, который составляет 29\% от валового сбора 2018 года. Проведен анализ аграрного сегмента информационно пространства официальных информационных источников. Предложены направления развития консультирования с использованием современных информационных 
технологий. Выделены преимущества внедрения системы электронного консультирования для различных категорий пользователей. Проанализированы потенциальный объем услуг бинарной системы для инновационного развития малого и среднего бизнеса. В качестве клиентской базы рассматриваются сельские домохозяйства, фермерские хозяйства и аграрные предприятия с объемом землепользования не выше 1 тыс га. Показано, что большой аграрный бизнес пользуется информацией непосредственно с мировых инновационных центров аграрной направленности. Значительное внимание уделено проблеме информационного обеспечения жителей сельских территорий.

Ключевые слова: информационное пространство; эффект маситаба; электронное сельскохозяйственное консультирование; цифровой разрыв; домохозяйства; фермерство; аграрные предприятия. 